\section{Prospects for graduates}

SIR - I am a recent $\mathrm{PhD}$ graduate, and Nature's manifesto for British science (Nature 353, 105; 1991) does not relieve my fears about the long-term prospects in science and technology and the likelihood of permanent employment in Britain for myself and my peers. Young people are certainly turning their backs on career in science, which, as the manifesto suggests, is because the infrastructure of British science is in a mess.

But I must agree with Hopkins and Rothwell (Nature 353, 692; 1991) that increasing the number of research studentships will only compound the already desperate state of funding of postgraduate training, and will certainly not restore the award of a research studentship as a valuable prize, which is one of the aims of the manifesto. The underfunding of research studentships by the government-financed research councils may be a root of subsequent underfunding of research as a whole.

The devaluation of students at an early stage in their career allows a certain amount of complacency to set in at higher levels as to the real value of the researcher. Apart from low salaries, perhaps a greater fear of the $\mathrm{PhD}$ graduate is the fear of not having a job at all, or accepting a short-term position in a field inappropriate to one's training. A more formal study programme to complement students' research activities would help the general background training of $\mathrm{PhD}$ students, making them a more marketable product. This and additional theoretical training is at present very much dependent upon the enthusiam and encouragement of a student's individual supervisor, which can be very unpredictable.

The manifesto does not go far enough on the question of job security. Why should an enthusiastic young scientist spend 6-10 years gaining two or even three specialist degrees to get only a $2-3$ year temporary job offer in the end in the form of a postdoctoral fellowship? There is no other profession where so much time and energy is rewarded so poorly, with young researchers beginning their precarious careers often funded only by the good grace of charitable benefactors. There is something to commend the argument that competition breeds success, and to some extent competion by groups for grants does raise scientific standards. But to new postdoctorates, this generally sows the seeds of insecurity, disillusionment and contempt, and is no way to begin a career. The assurance of a permanent job would not lead to complacency, apathy or 'inbreeding' within groups, as postgraduates would still wish to learn new tech- nology, to work with colleagues in different establishments and to collaborate with groups offering expertise in different disciplines.

Many young scientists will leave science in the near future not only for the easier pickings in the fields of commerce, economics and law, but also as a matter of survival. The unfortunate point is that they will have passed the most difficult hurdle of acquiring their PhD. Despite this, many people will pursue a career in science, but if science and technology in Britain are to advance into the twenty-first century, then some radical changes are needed.

\section{Department of Biochemistry}

and Cell Biology,

The Hunterian Institute,

Royal College of Surgeons of England, London WC2A 3PN, UK

\section{DNA sequences}

SIR - Much attention has recently been paid to the patent and intellectual property issues linked with the rapid accumulation of partial DNA sequences obtained from a large number of cDNA clones. During recent meetings, HGM 11 in London in August and Genome Sequencing in Hilton Head, South Carolina, in September, it appeared that efforts in the United States, the United Kingdom, France, Japan and elsewhere will yield several tens of thousands of cDNA sequences over the next few years. This situation had not been foreseen by the experts when the plans for the next five years of the Human Genome Initiative were formulated.

The current discussions are in my opinion mistaken, and it is time to consider the issue at the level of the ethics of knowledge. Accumulation of partial cDNA sequences is a service to the scientific community, supported by funds from foundations and government agencies, designed to facilitate and speed up acquisition of knowledge on the final product encoded by the transcripts, a limiting step in the development of diagnostic tests and therapeutic drugs. Integration of these gene landmarks together with polymorphic genetic markers within the physical map of the human genome will facilitate identification of disease genes, especially those for which no chromosomal anomaly is known.

The partial cDNA sequences represent part of our human heritage and as such should be placed under the protection of an international body such as UNESCO in order to ensure that the scientific community as a whole has immediate unrestricted access to the data as they accumulate. International cooperation and exchanges will also be essential to limit duplication of efforts.

Généthon, ChARLES AufFray

1 rue de l'Internationale,

91000 Evry, France and

CNRS, UPR 420 BP 8,

94801 Villejuif cedex, France

\section{Canada calling}

SIR - The telephone and the fax machine (Nature 353, 286; 1991) have been both a blessing and a curse. Both have speeded up communication, the exchange of information and the development of ideas. But we receive via the telephone unsolicited nonhuman intrusions and solicitations, and the fax is a means for transmission of junk mail. But rapid transmissions by telephone and fax are here to stay, and there will probably be other changes over the coming years.

We can all thank Mr Alexander Graham Bell but, to set the record straight, the telephone was 'invented' in Canada, not the United States. Bell, a Scot, had moved to Canada because of his health. He resided in Brantford, Ontario, where he uttered his now famous words to Watson in 1876. Bell did have close ties with Boston, and many of the components for the first telephone came from there. He later moved to the United States and took out US citizenship, a prerequisite for securing a US patent.

Bell thus joins a long list of Canadians who have migrated south to achieve fame and, more importantly I suppose, their fortune. Bell did retain his Canadian ties, maintaining a summer home in Nova Scotia which is still owned by his descendants.

International Joint Commission,

100 Ouellette Avenue,

Windsor, Ontario N9A 6T3, Canada

\section{Nikola Tesla}

SIR - In their 'Plea from Croatia' ( $\mathrm{Na}$ ture 353, 597; 1991), Ivica Vucak and Antonio Juretic inadvertently cast a light on 'cause and effect'. They cite the famous scientist Nikola Tesla (18581943) as a Croatian. Tesla was, indeed, proud of his native Croatian region, but he was also proud of his Serb nationality and upbringing. His father was the local Serbian Orthodox priest and his uncle a bishop. In other words, Tesla considered himself to be a Yugoslav. The final twist is that, during the Second World War, his father's parish church was razed to the ground by the Croat Fascist Ustashi.

38 Lebanon Park,

Y. KOVACH

Twickenham, Middlesex TW1 3DG, UK 